\title{
Metrical analysis of bovine bone remains from the Neolithic to the Bronze Age at the El Portalón site (Atapuerca, Burgos) in the Iberian context
}

\author{
M.A. Galindo-Pellicena ${ }^{\mathrm{a}, *}$, J.L. Arsuaga ${ }^{\mathrm{a}, \mathrm{b}}$, A. Pérez-Romero ${ }^{\mathrm{c}}$, E. Iriarte ${ }^{\mathrm{c}, \mathrm{d}}$, I. De Gaspar ${ }^{\mathrm{e}}$, \\ J.M. Carretero ${ }^{\mathrm{c}}$ \\ ${ }^{a}$ Centro Mixto UCM-ISCIII de Evolución y Comportamiento Humanos. C/Monforte de Lemos 5, pab 14, 28029, Madrid, Spain \\ ${ }^{\mathrm{b}}$ Departamento de Geodinámica. Estratigrafía y Paleontología Facultad de Ciencias Geológicas. Universidad Complutense de Madrid, Calle José Antonio Novais 12, 28040, \\ Madrid, Spain \\ ${ }^{\mathrm{c}}$ Laboratorio de Evolución Humana. Facultad de Humanidades y Comunicación. Universidad de Burgos. Edificio I+D +I. Plaza de Misael Bañuelos s/n 09001, Burgos, \\ Spain \\ ${ }^{\mathrm{d}}$ ARANZADI Geo-Q, b/ Kortasenebarri s/n, 48940, Leioa, Bizkaia, Spain \\ e Sección Departamental de Anatomía y Embriología. Facultad de Veterinaria. Universidad Complutense de Madrid, Avda. Puerta del Hierro s/n. Ciudad Universitaria, \\ 28040, Madrid, Spain
}

\section{A R T I C L E I N F O}

\section{Keywords:}

Metrical data

Bovines

Holocene

Zooarchaeology

Iberian peninsula

\begin{abstract}
A B S T R A C T
The discrimination of wild and domestic forms of animals is crucial to understanding the subsistence strategy of a site's inhabitants. In this study, a metrical analysis was carried out for the taxonomical identification of Bos taurus and Bos primigenius. Abundant bovine bone remains have been recovered from the El Portalón site's Neolithic, Chalcolithic, and Bronze Age levels. A metrical analysis and sex determination have been completed for these bone remains. The results of the metrical study suggest a significant decrease in bovine size during the transition from the Chalcolithic to the Bronze Age. The similar sex ratio (bulls/cows) among the levels and the similar mortality profile rule out management differences as a possible cause for this size change. The global trend towards aridification from the Middle Holocene onwards or the general climate event (4.2 Ka: transition Chalcolithic to Bronze Age) where social, demographic, and subsistence strategic changes occurred are considered probable causes of this decrease in cattle size.
\end{abstract}

\section{Introduction}

The auroch (Bos primigenius, Bojanus, 1827) is the ancestor of current domestic cattle livestock (Bos taurus, Linnaeus, 1758) (Leithner, 1927; Cordier-Goni, 1938; Poplin, 1983; Chaix, 1994; Clutton-Brock, 1999).

The aurochs were one of the most hunted species in the European Paleolithic. In the Iberian Peninsula, they were present from the Middle Pleistocene (Bos primigenius was found for the first time in Torralba; dated 350 ka according to Falgueres et al., 2006 and Ambrona site, dated around $200 \mathrm{ka}$ according to Santonja et al., 2014) to the Holocene. The most recent bone remains of this species were found at some Roman sites in the Basque Country (Altuna and Mariezkurrena, 2002). The aurochs probably inhabited wet habitats, such as river valleys, lake fringes, marshy forests (Van Vuure, 2005), and open woodlands (Kurtén, 1968).

The auroch is distinguished from domestic cattle by the morphology and the size of the horn corns (Guintard, 2005), among other features, in addition to the absolute size of individuals (Böyönki and y Bartosiewicz, 1987; Rowley-Conwy, 1995; Tekkouk and Guintard, 2007). The usual method for distinguishing between the domestic and wild form of the bovines is by size (metrical analysis) and by pattern of exploitation (sex and age) (Saña, 2013). In regards to the size, domestic cattle are smaller than their wild ancestors; nevertheless, there is a degree of overlap between both of them (Davis, 1987).

Finding a complete bovine cranium and completing the diagnostic measurements for distinguishing between domestic and wild form of bovines at an archaeological-palaeontological site is complicated, due to fragmentation (Bartosiewicz, 1998).

In the Iberian Peninsula, aurochs and cattle possibly began coexisting from the Neolithic. Cattle (along with sheep, goats, and pigs) were domesticated in the northern Levant during the 10th-9th millennia BCE (Peters et al., 1999; Helmer et al., 2005) and subsequently exported to Europe (Colledge et al., 2013). Domestic cattle constituted

\footnotetext{
* Corresponding author.

E-mail addresses: mangeles.galindo@fgua.es (M.A. Galindo-Pellicena), jlarfer@gmail.com (J.L. Arsuaga), apromero14@gmail.com (A. Pérez-Romero), eiriarte@ubu.es (E. Iriarte), idegaspar@vet.ucm.es (I. De Gaspar), jmcarre@ubu.es (J.M. Carretero).
} 


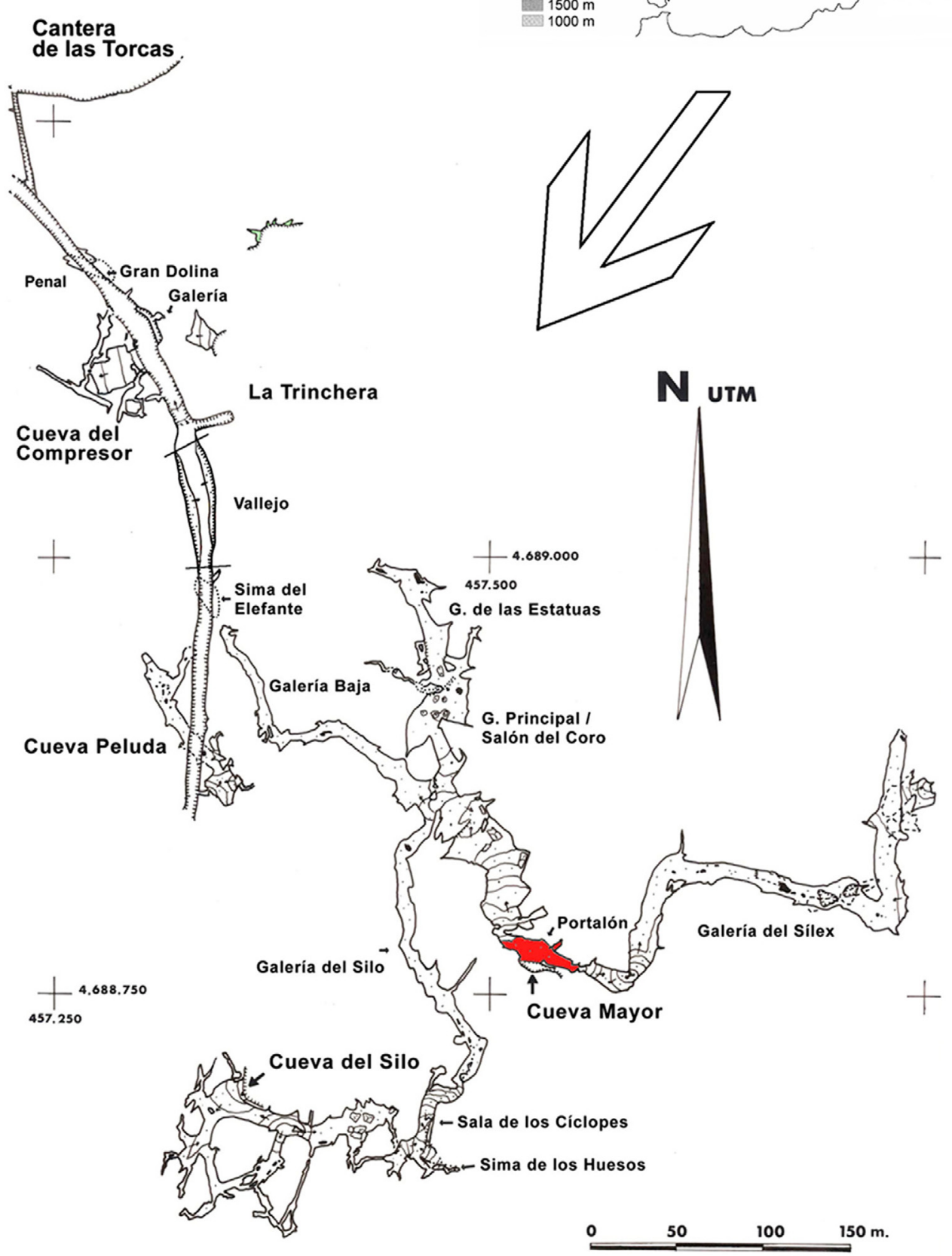

Fig. 1. Geographic location of the Sierra de Atapuerca and map of the Trinchera del Ferrocarril and Cueva Mayor-Cueva del Silo karst system showing the location of El Portalón in relation to other Atapuerca Pleistocene and Holocene sites, such as Gran Dolina, Galería, Sima del Elefante, Sima de los Huesos, Galería del Sílex, and Galería de las Estatuas. 
Table 1

Radiocarbon datings BP and Cal BP for the different levels of the El Portalón site (Carretero et al., 2008; Ortega et al., 2008).

\begin{tabular}{|c|c|c|c|c|}
\hline Levels & Profile & Epoch & Chronology (B.P.) & $\begin{array}{l}\text { Chronology cal. } \\
\text { BC }\end{array}$ \\
\hline \multirow[t]{4}{*}{ Level 1} & North & Roman Age & $1.000 \pm 10$ & $\begin{array}{l}980 \mathrm{AD} \text { a } 1060 \\
1080 \mathrm{AD} \text { a } 1150\end{array}$ \\
\hline & South & & $1.980 \pm 40$ & $50 \mathrm{BC}$ a $100 \mathrm{AD}$ \\
\hline & South & & $2.040 \pm 100$ & $370 \mathrm{BC}$ a $150 \mathrm{AD}$ \\
\hline & South & & $2.050 \pm 40$ & $170 \mathrm{BC}$ a $50 \mathrm{AD}$ \\
\hline Level $1 / 2$ & South & Transition & $2.490 \pm 40$ & 790 a 420 \\
\hline \multirow[t]{2}{*}{ Level 2} & South & Iron I Age & $2.490 \pm 40$ & 790 a 420 \\
\hline & South & & $2.510 \pm 40$ & $\begin{array}{l}790 \text { a } 500 \\
460 \text { a } 430\end{array}$ \\
\hline \multirow[t]{2}{*}{ Level 3} & South & Middle Bronze Age & $3.330 \pm 40$ & 1.760 a 1.440 \\
\hline & South & & $3.560 \pm 50$ & 2.030 a 1.750 \\
\hline \multirow[t]{2}{*}{ Level 3/4 } & Norte & Transition & $3.330 \pm 60$ & 1.750 a 1.490 \\
\hline & Norte & & $3.560 \pm 40$ & 2.010 a 1.760 \\
\hline \multirow[t]{3}{*}{ Level 4} & Sur & Early Bronze Age & $3.490 \pm 40$ & 1.910 a 1.700 \\
\hline & Sur & & $3.680 \pm 40$ & 2.190 a 2.170 \\
\hline & & & & 2.150 a 1.940 \\
\hline \multirow[t]{7}{*}{ Level 5} & Sur & Early Bronze Age & $3.630 \pm 40$ & 2.130 a 2.080 \\
\hline & & & & 2.060 a 1.890 \\
\hline & Sur & & $3.670 \pm 40$ & 2.190 a 2.180 \\
\hline & & & & 2.140 a 1.940 \\
\hline & Sur & & $3.700 \pm 70$ & 2.290 a 1.900 \\
\hline & Norte & & $3.740 \pm 40$ & 2.280 a 2.030 \\
\hline & Norte & & $3.760 \pm 40$ & 2.290 a 2.040 \\
\hline Level 6 & Sur & Transition & $3.910 \pm 70$ & 2.580 a 2.200 \\
\hline Level 7/8 & Sur & Chalcolithic & $4.440 \pm 50$ & 3.340 a 2.920 \\
\hline \multirow[t]{10}{*}{ Level 9} & Sur & Mesolithic/ & $4.990 \pm 40$ & 3.930 a 3.860 \\
\hline & & Neolithic & & 3.810 a 3.640 \\
\hline & Norte & & $5.230 \pm 40$ & 4.150 a 4.120 \\
\hline & & & & 4.070 a 3.960 \\
\hline & Norte & & $6.070 \pm 110$ & 5.290 a 4.710 \\
\hline & Norte & & $6.100 \pm 50$ & 5.210 a 5.160 \\
\hline & & & & 5.150 a 4.840 \\
\hline & Norte & & $7.790 \pm 40$ & 6.680 a 6.500 \\
\hline & Sur & & $6.270 \pm 40$ & 5.320 a 5.210 \\
\hline & & & & 5.170 a 5.080 \\
\hline \multirow[t]{2}{*}{ Level 10} & Sur & Upper Pleistocene & $16.980 \pm 80$ & 18.770 a 17.780 \\
\hline & Sur & & $30.300 \pm 190$ & \\
\hline
\end{tabular}

the most common livestock (together with ovicaprines and pigs) and the basis for the economy and nutrition of inhabitants from Metal Age societies in the Iberian Peninsula (Saña, 2013).

The domestication process began with a reduction in the animals' body size (Davis, 1987; Uerpmann, 1978) across Western Europe followed by a subsequent decrease in size in domestic animals, particularly cattle, between the Neolithic and the Iron Age (Matolcsi, 1970; Altuna, 1980; Audoin-Rouxeau, 1991; Valenzuela-Oliver et al., 2013; Manning et al., 2015; Trentacoste et al., 2018). This decrease in the animals' size could be due to the preference for smaller specimens because they are more manageable (Clutton-Brock, 1999) or to the intensification of herding strategies through sub-adult breeding (Manning et al., 2015). Nevertheless, we also have to take into account sexual dimorphism (cows and bulls), the age of the individuals, and the geographical area where they live due to its influence on animal size. The breeding of female or male cattle depends on the nature of the economy - meat, milk or traction animals (Davis et al., 2018). Cattle livestock have considerable sexual dimorphism as males are larger than females, thus possibly driving the difference in size. Sexual dimorphism is more easily observed in certain measurements of the anatomical elements in the cattle, such as the width and robustness of the metacarpals (Higham, 1969; Guintard, 1998; Guintard and Borvon, 2009). Genetic methods also help in the sexual identification (Svensson and Götherström, 2008; Davis et al., 2012; Telldahl et al., 2012) and complete the zoorchaeological methods.

According to Davis et al. (2013), metrical analysis of animal bones from Portuguese sites suggests the aurochs in Mesolithic levels were larger than cattle from the Chalcolithic and younger levels. The lack of large specimens after the Chalcolithic supports Castaños (1991), who confirms the aurochs disappeared during or immediately after the Chalcolithic in the occidental part of Iberian Peninsula.

A cattle size reduction from the Mesolithic to the Bronze Age was identified not only in Portugal but also in other regions of the Iberian Peninsula. For instance, Altuna (1980) identified the same trend in the Basque Country, where cattle livestock decreased in size from the Neolithic to the Bronze Age levels.

Castaños Ugarte (2005) already analysed domestic cattle in the Early, Middle and Final Bronze Age, as well as the Roman levels from the El Portalón site. According to his observations, Bos taurus was the second-best represented taxon in Early Bronze Age levels (NISP $=158$ ), the third-best represented taxa in Middle Bronze Age levels (NISP $=360$ ), and the best represented taxa in Late Bronze Age levels $(\mathrm{NISP}=433)$.

Later, with new stratigraphic levels established (Carretero et al., 2008; Pérez-Romero et al., 2017) and the material recovered from 2007 to 2011, Galindo-Pellicena (2014) identified domestic cattle (Bos taurus) in the Chalcolithic (NISP $=615$; MNI $=5$ ) and Bronze Age levels (NISP $=725$; MNI $=9$ ), as one of the three most represented taxa, while few remains of possible Bos primigenius were found, as in the levels of Chalcolithic (NISP $=5$; MNI $=2$ ) and Bronze Age (NISP $=1$; MNI = 1).

Regarding the subsistence strategy in the Chalcolithic and Bronze Age levels from the El Portalón site, the mortality profile for the cattle suggests a mixed livestock exploitation represented in both levels. The population's subsistence is mixed, obtaining both primary and secondary products from the animals. In the Chalcolithic level, mortality profiles and butchering marks suggest that all domestic and wild species were used for meat. Cattle seems to be used more for milk, dairy products, and reproduction in the case of females, and as pack or draft animals (pathologies) in the case of males (Galindo-Pellicena et al., 2017). A lesser percentage of cattle is used for meat consumption, and adult individuals are slaughtered and eaten after having been used throughout their lives. In the Bronze Age level, cattle are mainly exploited for milk and reproduction in the case of females and also as pack or draft animals. As in the Chalcolithic, less cattle meat is consumed and adult individuals are also used for their meat (GalindoPellicena, 2014; Galindo-Pellicena et al., 2017).

With this background in mind, the aims of this work are 1) to anatomically and taxonomically identify the bone remains from the El Portalón site in order to distinguish the domestic (Bos taurus) from the wild (Bos primigenius) bovines through the metrical analysis of the anatomical elements; 2) to determine the sex of the cattle by means of the metrical analysis of metacarpals and phalanges; and 3) to infer the size evolution of the bovines from the Neolithic to the Bronze Age at the El Portalón site (Atapuerca, Burgos).

\section{The site}

The Sierra de Atapuerca is located in the north of Spain and has a maximum altitude of $1085 \mathrm{~m}$ asl. Atapuerca is situated about $15 \mathrm{~km}$ to the east of the city of Burgos. The Cueva Mayor-Cueva del Silo karst system is located in the southern sector of the Sierra de Atapuerca. It constitutes one of the most significant cave systems in the Duero River Basin, with $3700 \mathrm{~m}$ of subterranean passages. It comprises El Portalón, Sima de los Huesos, El Mirador, Galería del Sílex, and Galería de las Estatuas (Ortega, 2009) (Fig. 1).

The entrance to the Cueva Mayor-Cueva del Silo cave systems consists of a large chamber known as "El Portalón" (Arsuaga et al., 1997). El Portalón at Cueva Mayor is an important Holocene archaeological site that was excavated in the 1970s by Prof. Apellániz and his team. The faunal remains were studied by Castaños Ugarte, 2005.

A new phase of excavations was initiated in 2000 as part of the Atapuerca Research Project, which are still ongoing. Excavations in 2000 revealed a deep stratigraphic sequence with human occupations 
Table 2

Measurements taken for the study. Modified by Wright and Viner-Daniels. (2015).

\begin{tabular}{|c|c|c|c|}
\hline Anatomical Element & Measurement & Description & Reference \\
\hline \multirow[t]{2}{*}{ Atlas } & $\mathrm{H}$ & Height & Albarella and Payne (2005) \\
\hline & BFcr & Width of cranial articular surface & von den Driesch (1976) \\
\hline Scapula & SLC & Width of collum & \\
\hline \multirow[t]{2}{*}{ Humerus } & $\mathrm{BT}$ & Width of trochlea & Payne and Bull (1988) \\
\hline & HTC & Minimum diameter of trochlea & \\
\hline \multirow[t]{4}{*}{ Radius } & GL & Greatest length & von den Driesch (1976) \\
\hline & $\mathrm{Bd}$ & Width of distal end & \\
\hline & BFp & Width of the humeral articular surface & \\
\hline & $\mathrm{Bp}$ & Width of proximal end & \\
\hline \multirow[t]{9}{*}{ Metacarpus III and IV } & GL & Greatest length & von den Driesch (1976) \\
\hline & SD & Smallest diameter of the diaphysis & Davis (1992, 1996) \\
\hline & $\mathrm{BFd}$ & Width of the distal end & \\
\hline & Dd & Depth of the distal end & \\
\hline & BatF & Width at the distal fusion line & \\
\hline & a & Width of medial condyle & \\
\hline & $\mathrm{b}$ & Width of lateral condyle & \\
\hline & 3 & Diameter of the lateral part of the medial condyle & \\
\hline & 6 & Diameter of the medial part of the lateral condyle & \\
\hline Femur & DC & Depth of the caput & von den Driesch (1976) \\
\hline \multirow{3}{*}{ Tibia } & GL & Greatest length & von den Driesch (1976) \\
\hline & $\mathrm{Bd}$ & Breadth of the distal end & \\
\hline & $\mathrm{Dd}$ & Diameter of the diaphysis & \\
\hline \multirow[t]{3}{*}{ Astragalus (excluding 'porous' specimens) } & GLl & Greatest length of the lateral side & von den Driesch (1976) \\
\hline & GLm & Greatest length of the medial side & \\
\hline & $\mathrm{Bd}$ & Width of the distal end & \\
\hline \multirow[t]{2}{*}{ Calcaneus } & GL & Greatest length & von den Driesch (1976) \\
\hline & GD & Greatest depth & Albarella and Payne (2005) \\
\hline \multirow[t]{9}{*}{ Metatarsus III and IV } & GL & Greatest length & von den Driesch (1976) \\
\hline & $\mathrm{SD}$ & Smallest diameter of the diaphysis & \\
\hline & BFd & Width of the distal end & \\
\hline & Dd & Depth of the distal end & \\
\hline & BatF & Width at the distal fusion line & \\
\hline & a & Width of medial condyle & \\
\hline & $\mathrm{b}$ & Width of lateral condyle & \\
\hline & 3 & Diameter of the lateral part of the medial condyle & \\
\hline & 6 & Diameter of the medial part of the lateral condyle & \\
\hline
\end{tabular}

Table 3

NISP (number of identified specimens) and \% (relative frequencies) of the taxa from the Neolithic to the Bronze Age at the El Portalón site.

\begin{tabular}{|c|c|c|c|c|c|}
\hline NISP (\%NISP) & Middle Bronze Age & Early Bronze Age & Late Chalcolithic (habitat) & Early Chalcolithic (funerary) & Neolithic \\
\hline Bos taurus & $309(37.01)$ & $245(26.23)$ & 694 (34.19) & $184(16.53)$ & $146(26.5)$ \\
\hline total ovicaprines & $262(31.38)$ & 338 (36.19) & $1065(52.46)$ & $724(65.05)$ & $182(33.03)$ \\
\hline Sus sp. & $58(6.95)$ & $84(8.99)$ & $133(6.55)$ & $112(10.06)$ & $66(11.98)$ \\
\hline Equus sp. & $98(11.74)$ & $162(17.34)$ & $30(1.48)$ & $17(1.53)$ & 0 \\
\hline Bos cf. primigenius & $1(0.12)$ & 0 & $4(0.2)$ & 0 & $8(1.45)$ \\
\hline Sus scrofa & 0 & $3(0.32)$ & $4(0.2)$ & 0 & 0 \\
\hline Equus ferus & 0 & 0 & 0 & 0 & 89 (16.15) \\
\hline Cervus elaphus & $15(1.8)$ & $11(1.18)$ & $6(0.3)$ & $11(0.99)$ & $24(4.36)$ \\
\hline Capreolus & $1(0.12)$ & $1(0.11)$ & $3(0.15)$ & $2(0.18)$ & $4(0.73)$ \\
\hline Canis familiaris & $61(7.31)$ & $34(3.64)$ & $39(1.92)$ & $11(0.99)$ & $7(1.27)$ \\
\hline Vulpes & 0 & $6(0.64)$ & $1(0.05)$ & $1(0.09)$ & 0 \\
\hline Mustela sp. & 0 & 0 & 0 & $2(0.18)$ & 0 \\
\hline Carnivora indet. & 0 & 0 & $4(0.2)$ & $4(0.36)$ & 0 \\
\hline Leporidae indet. & $30(3.59)$ & $50(5.35)$ & $29(1.43)$ & $23(2.07)$ & $11(2)$ \\
\hline Chelonia indet. & 0 & 0 & 0 & $5(0.45)$ & 0 \\
\hline Avian remains & 0 & 0 & $17(0.84)$ & $14(1.26)$ & $14(2.54)$ \\
\hline \multirow[t]{2}{*}{ Fish } & 0 & 0 & $1(0.05)$ & $3(0.27)$ & 0 \\
\hline & 835 & 934 & 2030 & 1113 & 551 \\
\hline
\end{tabular}

starting at the beginning of the Late Pleistocene, and a complete set of radiocarbon dates were obtained. Dates spanned from 30,000 years BP to 1000 years BP (Clark et al., 1979; Carretero et al., 2008; PérezRomero et al., 2015).

Eleven stratigraphic levels (from 0 to 10 ) were recognised in this sequence, recording human activity during the Late Paleolithic, Mesolithic, Neolithic, Chalcolithic, Bronze Age, Iron Age I, and Roman and Medieval periods (Carretero et al., 2008; Ortega et al., 2008). The Bronze Age levels were divided into the Early and Middle Bronze Age. The faunal remains were studied by Galindo-Pellicena (2014).
The El Portalón stratigraphic sequence presents two main sedimentary units: the lower unit (level 10) pertains to the last third of the Late Pleistocene where there is a weak presence of human activity while the upper cultural sequence indicates the existence of an intense human occupation during the Holocene (Carretero et al., 2008; Ortega et al., 2008; Pérez-Romero et al., 2017; Valdiosera et al., 2018).

The levels that are the object of this study are the Neolithic, Chalcolithic, and Bronze Age. The Holocene occupation of the site began in the Neolithic (level 9), about which very little is known, as this level is currently being excavated. These occupations must have 
Table 4

Sex discrimination carried out with the metrical data taken from the bovine metacarpals from the Neolithic to the Bronze Age levels at the El Portalón site. BFd: distal breadth (Davis, 1992, 1996).

\begin{tabular}{|c|c|c|c|}
\hline Cultural levels & Label & BFd (metacarpal) & $\begin{array}{l}\text { Sex } \\
\text { determination } \\
\text { (Fig) }\end{array}$ \\
\hline \multirow[t]{3}{*}{ Bronze Age } & ATP18.UE2003N.934 (l) & 50.8 & female \\
\hline & ATP19.UE2004s.1061 (1) & 54.23 & female \\
\hline & CMI.C2.98.1 & 57.41 & female \\
\hline \multirow[t]{3}{*}{ Chalcolithic } & ATP08.UE21.nivel7.86 ® & 60.48 & Oxen $/$ male ${ }^{\mathrm{a}}$ \\
\hline & ATP08.UE4.O46.72 ® & 54.28 & Female $^{\mathrm{a}}$ \\
\hline & ATP08.UE4.ON45.9 ๑ & 53.17 & Female $^{\mathrm{a}}$ \\
\hline \multirow[t]{3}{*}{ Neolithic } & ATP19.UE530.730 ® & 62.85 & Male \\
\hline & AP16.UE519.112 (1) & 79.2 & Bos primigenius \\
\hline & ATP19.UE530.928 & 52.8 & female \\
\hline
\end{tabular}

a Galindo-Pellicena et al. 2017; (1): left; (R): right. involved nomadic populations in which livestock and agriculture probably supplemented hunting (study is in process). The Neolithic sequence culminates in a tumulus structure (Chalcolithic) with funerary characteristics. The 2012 excavation revealed a well-preserved burial of a child, accompanied by grave goods, as well as uncovering a nearly complete skeleton of an immature Bos taurus and other bone remains in anatomical connection (Pérez-Romero et al., 2017). In 2002, two sheep in anatomical connection were found (Carretero et al., 2008) in the same level as the child and the calf found in 2012. Both of them dated to a similar chronology. It has been considered the same funerary context (Pérez-Romero et al., 2017). The habitat context in the Final Chalcolithic is included in this study and the continuous sequence of the Bronze ages (level 5 to 3 ) represent the best understood period due to continuous excavation, divided between the Early Bronze Age (level 5) and the Middle Bronze Age (level 3 and 4) (Pérez-Romero et al., 2015).

Level 3 (dates from $3330 \pm 70$ to $3560 \pm 50$ years BP; 1440-2030 years cal. BC) corresponds to the Middle Bronze Age; level 4

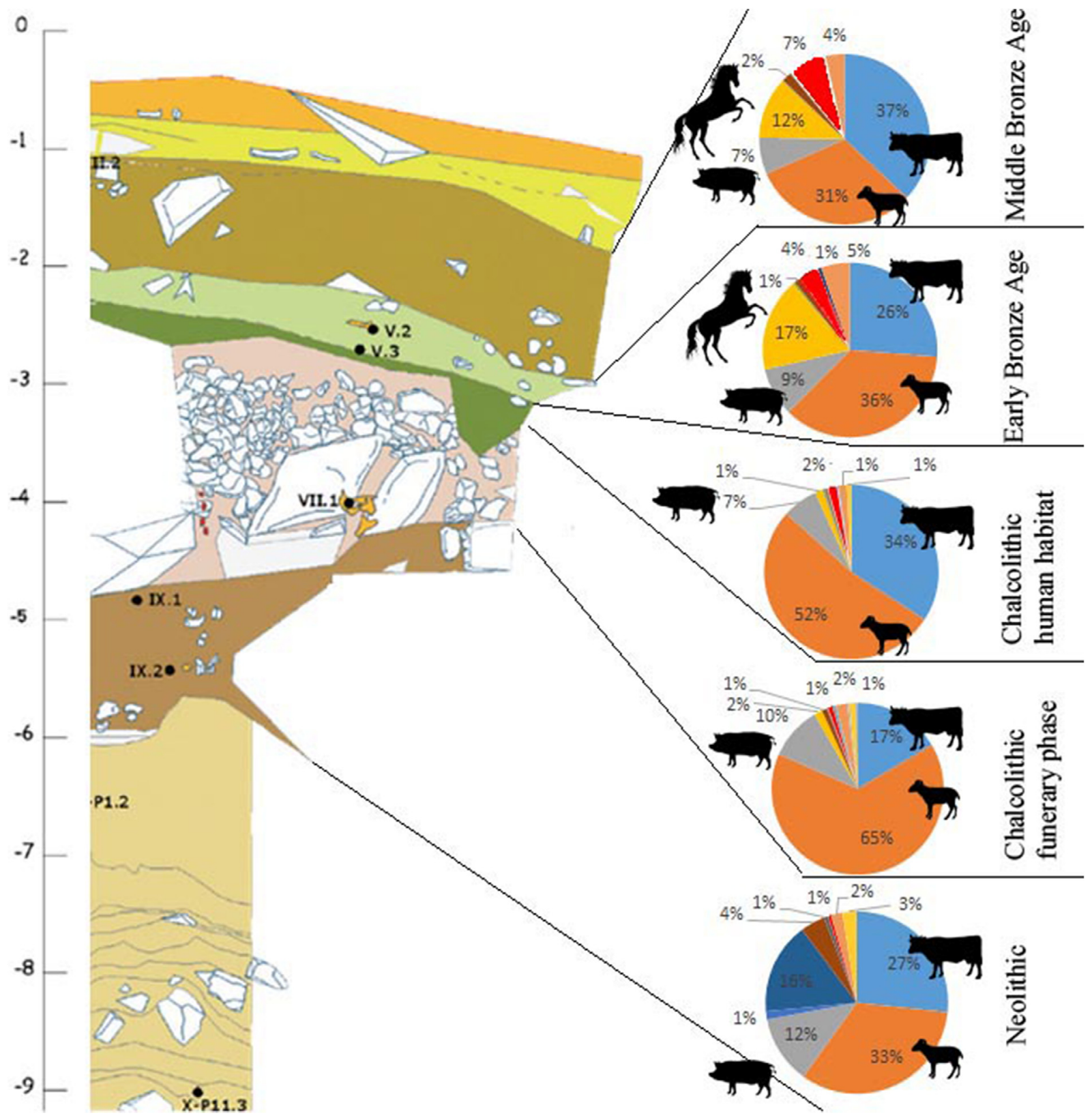

Fig. 2. Stratigraphic sequence from the Neolithic to the Bronze Age at the El Portalón site and the representation of the results of the relative frequency for the different species. See Table 3. The cattle livestock is represented in blue. 


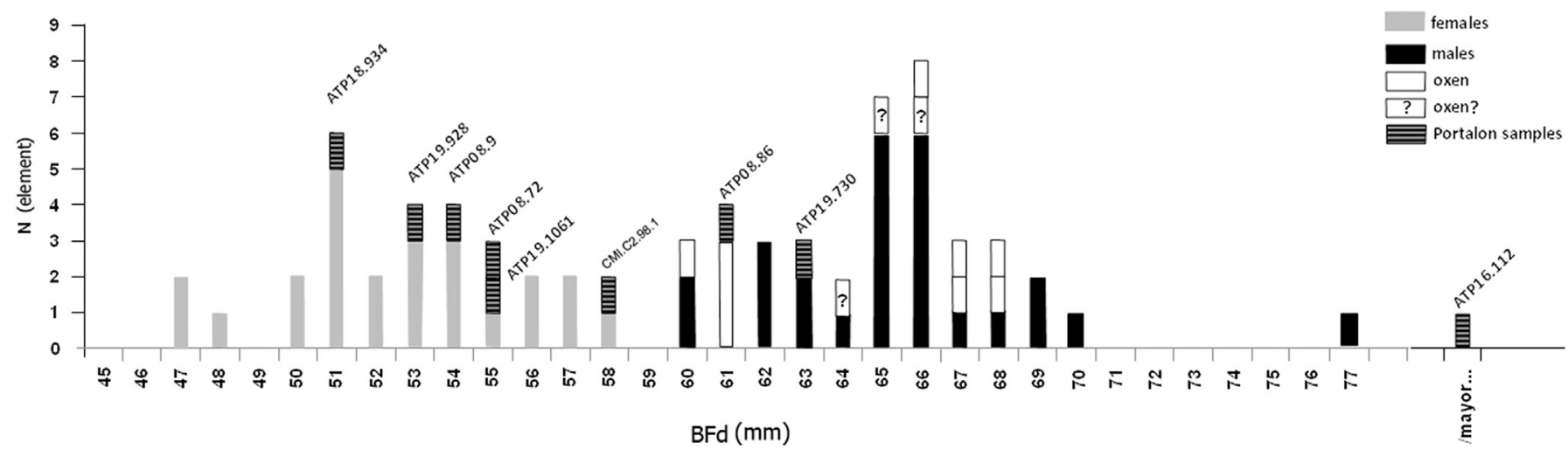

Fig. 3. Cattle size variation (BFd: distal breadth) between metacarpals from females (grey), males (black), oxen (white), and uncertain oxen (white with ?) from the Chalcolithic at the Valencina de la Concepción (Hain, 1982), Cerro de la Virgen (von den Driesch, 1972), and Zambujal (Von den Driesch and Boessneck, 1976) sites. The metacarpals from the Neolithic to the Bronze Age from the El Portalón site are included in the histogram (streaked).

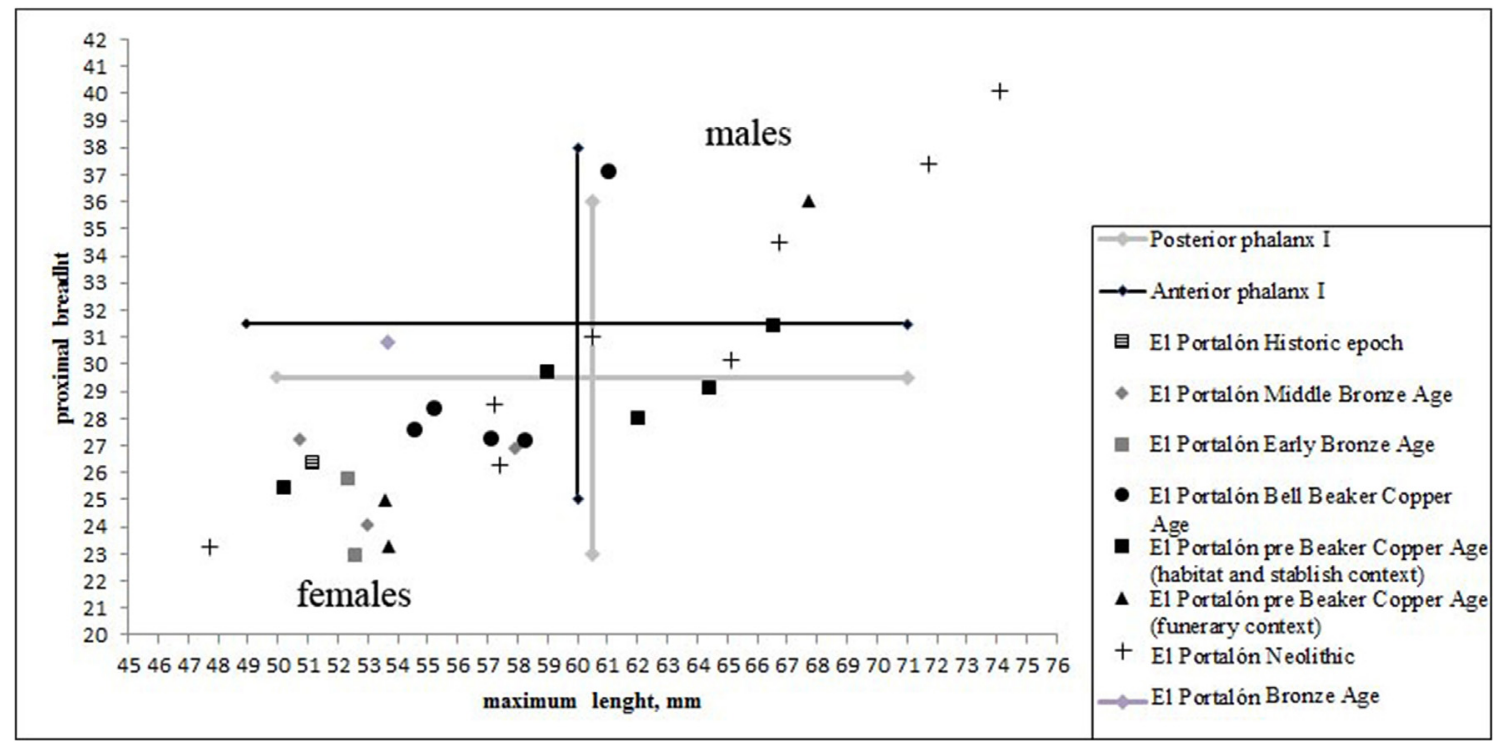

Fig. 4. Data range from the minimum and maximum data (diamonds: black for anterior phalanx and grey diamond for posterior phalanx) of the greatest length (GL) and proximal breadth (Bp) for I phalanx from the Chalcolithic bovines at Valencina de la Concepción (Hain, 1982) and Zambujal sites (Von den Driesch and Boessneck, 1976), which are represented in the black and grey cross. Scatter plot of the I phalanges data from the Neolithic, Pre-Beaker and Beaker Copper Age, and Early and Middle Bronze Age cattle at the El Portalón site (Atapuerca, Burgos).

(from $3490 \pm 40$ to $3680 \pm 40$ years BP; $1910-2190$ yearscal. BC) and level 5 (from $3630 \pm 40$ to $3760 \pm 40$ years BP; 1890-2290 years cal. BC) correspond to the Early Bronze Age. Level 6 (dates from $3910 \pm 70$ years BP; 2580-2200 years cal. BC) and level 7 (dates from $4440 \pm 50$ years BP; 3340-2920 years cal. BC) correspond to the Chalcolithic horizon; level $8 / 9$ (dates from $7790 \pm 50$ to $4990 \pm 40$ years BP; $6680-3690$ years cal. BC) correspond to the Neolithic (Carretero et al., 2008; Ortega et al., 2008). See Table 1.

\section{Material and methods}

The material included in this study is composed of 1582 bovine bone remains from the Neolithic to the Bronze Age levels (recovered in the 1980s and during current excavations from 2007 to 2019) at the El Portalón site (Atapuerca, Burgos). The metrical analysis was carried out by taking 188 measurements of the 87 postcranial anatomical elements (enough complete remains to be measured): 23 from the Neolithic, 33 from the Chalcolithic, and 31 from the Bronze Age levels. The postcranial remains used for the metrical analysis include talus, calcaneus, tibia, femur, humerus, radius, metapodials, and first phalanges. The teeth measurements are not included in this study because the sample sizes were generally small, such as the material from El Portalón as the reference samples for comparison (Wright and Viner-Daniels, 2015).

Some of this data set, particularly the bone remains recovered in the excavations during the 1980s directed by Prof. Apellániz and included in the Bronze Age levels, were studied by Castaños Ugarte, 2005 and as part of a PhD thesis (Galindo-Pellicena, 2014). The rest of the material has never been published before.

Anatomical and taxonomical identification of the bone remains from the Neolithic to the Bronze Age at the El Portalón site was carried out using atlases of animal anatomy (Schmid, 1972; Pales and Garcia, 1981; Barone, 1999) and the collection of comparative anatomy at the UCM-ISCIII Centre for Human Evolution and Behaviour in Madrid.

The metrical data were measured using a Sylvac digital caliper (03.02/SYL-235-F, D, E/681.046-100) to the nearest tenth of a millimeter, following the measurements from von den Driesch (1976), Payne and Bull (1988), Davis (1992, 1996), and Albarella and Payne (2005) (Table 2 for the measurements). The complete bones or bone 
Table 5

Metrical data for the I phalanxes from the Neolithic to the Bronze Age levels at the El Portalón site. GL: greatest length; Bp: proximal breadth (von den Driesch, 1976).

\begin{tabular}{|c|c|c|c|c|}
\hline PERIOD & LABEL (phalanx I) & GL & Bp & Sex Fig. 4 \\
\hline \multirow[t]{4}{*}{ Middle Bronze Age } & CMI-D4-55-3 & 53 & 24.08 & fem \\
\hline & CMI-C4-53-1 & 50.73 & 27.21 & fem \\
\hline & CMI-A2-55-1 & 34.36 & 27.7 & fem \\
\hline & CMI-D4-58-1 & 57.93 & 26.92 & fem \\
\hline \multirow[t]{2}{*}{ Early Bronze Age } & CMI-C4-72-1 & 52.59 & 22.97 & fem \\
\hline & CMI-D4-70-1 & 52.34 & 25.78 & fem \\
\hline Bronze Age & ATP19.UE2003N.864 & 53.66 & 30.8 & fem \\
\hline \multirow[t]{5}{*}{ Bell Beaker Copper Age } & АTP08O46UE4.128 & 58.25 & 27.15 & fem \\
\hline & ATP08O46UE9.26 & 61.05 & 37.08 & male \\
\hline & ATP08M47UE4.128 & 57.12 & 27.23 & \\
\hline & ATP07M45.UE4.131 & 54.6 & 27.54 & \\
\hline & ATP08N46.UE4.135 & 55.25 & 28.35 & \\
\hline \multirow{6}{*}{$\begin{array}{l}\text { Pre Beaker Copper Age } \\
\text { (habitat and stablish } \\
\text { context) }\end{array}$} & ATP10.UE23.229 & 66.52 & 31.41 & male \\
\hline & ATP11.UE23a.167 & 62 & 28 & \\
\hline & ATP11.UE23a.166 & 64.39 & 29.13 & \\
\hline & ATP11.UE23a.609 & 52 & - & fem \\
\hline & ATP09.UE52.606 & 59.01 & 29.73 & fem \\
\hline & ATP09.UE52.565 & 50.17 & 25.43 & fem \\
\hline \multirow{3}{*}{$\begin{array}{l}\text { Pre Beaker Copper Age } \\
\text { (funerary context) }\end{array}$} & ATP12.UE64.1311 & 53.6 & 25 & fem \\
\hline & ATP14.UE79.389 & 67.7 & 36.05 & male \\
\hline & ATP12.UE64.1274 & 53.68 & 23.3 & fem \\
\hline \multirow[t]{9}{*}{ Neolithic } & ATP18.UE530.952 & 57.23 & 28.53 & fem \\
\hline & ATP19.UE530.550 & 74.1 & 40.1 & \\
\hline & АТР18.UE549.1143 & 60.52 & 31 & male \\
\hline & ATP18.UE549.1286 & 57.4 & 26.26 & fem \\
\hline & ATP19.UE537.60 & 66.75 & 34.5 & male \\
\hline & ATP19.UE549.957 & 65.14 & 30.17 & male \\
\hline & ATP19.UE548.1171 & 47.7 & 23.23 & fem \\
\hline & ATP19.UE537.60 & 67.03 & 33.65 & male \\
\hline & АТР16.536.323 & 71.7 & 37.4 & \\
\hline
\end{tabular}

${ }^{\mathrm{a}}$ Galindo-Pellicena et al.2017

Table 6

Relative frequencies of bulls and cows from the Neolithic to the Bronze Age levels (expressed as percentages) and 95\% lower (LCI) and upper confidence interval (UCI).

\begin{tabular}{llllllll}
\hline & N & $\%$ bulls & $95 \%$ LIC & $95 \%$ UIC & \%cows & LIC & UIC \\
\hline Neolithic & 9 & 55.56 & 21.2009 & 86.3004 & 44.44 & 13.6996 & 78.7991 \\
Chalcolithic & 13 & 23.08 & 5.03811 & 53.8132 & 79.92 & 46.1868 & 94.9619 \\
Bronze Age & 9 & 0 & 0 & 33.6267 & 100 & 66.3733 & 100
\end{tabular}

parts that are complete enough to be measured were used for metrical analysis. The material used for the study was the postcranial bones that survived taphonomic processes. The cases of fusing or unfused bones have been indicated in the manuscript.

The distal width (BFd) of the metacarpals has been used to determine the sex. They are very sexually dimorphic and the best elements for sex discrimination. For comparison we use the histogram comparing individuals of known sex from the different Iberian sites found in chronologies that are similar to the El Portalón site: one Chalcolithic male from the Valencina de la Concepción site in Sevilla (Hain, 1982), as well as 16 females, 17 males, four oxen and nine oxen with doubt (?) from the Chalcolithic from Cerro de la Virgen in Granada (von den Driesch, 1972), and one male and one female from the Chalcolithic from the Zambujal site in Portugal (Von den Driesch and Boessneck, 1976).

The greatest length (GL) and proximal width (Bp) of the first phalanges were used as well in order to determine the sex due to their abundance and complete preservation. In this case, a scatter plot was used for comparison with other phalanges of known sex from the Valencina de la Concepción (Hain, 1982) and Zambujal sites (Von den Driesch and Boessneck, 1976).

Using univariant analysis and the multiple proportion C (confidence interval) test (Past version 3.15), we examine the overlapping between the confidence interval of the frequency of cows and bulls in order to verify the influence sexual dimorphism has on the size of the cattle.

For taxonomical identification, scatter plots and the log ratio technique (LSI) were used for distinguishing between the domestic and wild forms of bovines and for observing size evolution during the Holocene. The $\log$ ratio technique is used to increase sample size and allows for comparisons to be made between assemblages (Simpson et al., 1960; Meadow, 1999). The log ratio is a size index scaling technique which compares our measurements to the measurements of a standard individual or population (Payne and Bull, 1988).

Using univariant analysis and the bootstrap test (Past version 3.25), we examine the overlapping between the confidence interval of mean values of LSI (log ratio standard index) in order to check for significant differences in the size of the cattle.

The measurement data set of the auroch population from the Ilford site (Essex), dated to Marine Isotope Stage (MIS) 7 (186-242 kya), was used as the standard population (Wright, 2013; Wright and VinerDaniels, 2015).

\section{Results}

The number of identified specimens (NISP) of bovines (wild and/or domestic forms) is included in Table 3. The domestic form constitutes the second-best represented taxa in the Neolithic, Early and Late Chalcolithic, and Early Bronze Age after ovicaprines. In the Middle Bronze Age, Bos taurus constitutes the best represented taxa (Table 3 and Fig. 2). In terms of domestic bovines (Bos taurus), a minimum number of nine individuals was estimated in the Neolithic, 13 in the Chalcolithic, and nine in Bronze Age levels (with the metacarpals). Regarding wild bovines (Bos cf. primigenius/Bos primigenius), a minimum number of three individuals was estimated in the Neolithic (with one lower M3, one metacarpal and one third phalanx from different stratigraphic units), two in the Chalcolithic (with one first phalanx and one atlas from different stratigraphic units) and one in the Bronze Age levels (third phalanx).

\subsection{Sex determination (cows versus bulls)}

The sex determination is established based on the size distribution of the metacarpal distal width for different Iberian samples. The metacarpal distal width of the bovines from the Neolithic, Chalcolithic, and Bronze Age levels at the El Portalón site have been included in this histogram (Fig. 3 and Table 4).

In the Neolithic level, three metacarpals from the Portalón site are subject to measurement: the distal width of ATP16.112 is well outside the size range variation for domestic forms of bovines, so this is believed to belong to Bos primigenius. The metacarpal distal width ATP19.730 falls within the size variation for the domestic bulls from the Iberian sites, and the metacarpal ATP19.928 is included in the size variation for the domestic cows (see Fig. 3).

In the Chalcolithic level, another three bovine metacarpals were discovered that are subject to measurement. The distal width of the metacarpal ATP08.UE4.O46.72 and ATP08.UE4.ON45.9 fall within the metrical range of variation for the cows, according to the scatter plot with measurements from the Moncín site (Galindo-Pellicena et al., 2017), and the metacarpal ATP08.UE21.nivel7.86 falls within the metrical range of variation for males (Galindo-Pellicena et al., 2017) and oxen or males (Fig. 3).

In the Bronze Age levels, three bovine metacarpals were discovered and subject to measurement: the distal width of the metacarpals ATP18.UE2003N.934, ATP19.UE2004s.1061, and CMI.C2.98.1 falls within the metrical range of variation for the cows (Fig. 3).

Due to the abundance of the bovine I phalanges in the El Portalón site, a scatter plot of the greatest length (GL) and proximal breadth (Bp) 
Table 7

Postcranial element measurements for Neolithic bovines from the El Portalón site (Atapuerca), the standard population from the Ilford site, and LSI.

\begin{tabular}{|c|c|c|c|c|c|}
\hline Neolithic & VdD (1976) and Davis $(1992,1996)$ & Measurements (mm) & standard & ratio & LSI \\
\hline ATP17.UE545.F667 & astragalo GLl & 62.8 & 95.15 & 0.660 & -0.180 \\
\hline ATP14.UE94.825 & & 63.5 & 95.15 & 0.667 & -0.176 \\
\hline ATP17.UE545.F667 & astragalo GLm & 68.8 & 87.33 & 0.788 & -0.104 \\
\hline ATP14.UE94.825 & & 56.8 & 87.33 & 0.650 & -0.187 \\
\hline ATP17.UE545.F667 & astragalus $\mathrm{Bd}$ & 40.6 & 66.7 & 0.609 & -0.216 \\
\hline ATP14.UE94.825 & & 38.5 & 66.7 & 0.577 & -0.239 \\
\hline ATP18.UE543.579 & Hu BT & 94.31 & 115.26 & 0.818 & -0.087 \\
\hline ATP19.588 & & 68 & 115.26 & 0.590 & -0.229 \\
\hline ATP15.UE522.935 & Hu HTC & 31.95 & 50.42 & 0.634 & -0.198 \\
\hline ATP18.UE543.579 & & 41.3 & 50.42 & 0.819 & -0.087 \\
\hline ATP18.755 & Ti Bd & 69.8 & 91.6 & 0.762 & -0.118 \\
\hline ATP18.755 & Ti Dd & 49.5 & 69.23 & 0.715 & -0.146 \\
\hline ATP14.UE99.1001 & Mt SD & 22 & 47.02 & 0.468 & -0.330 \\
\hline ATP19.UE530.803 & & 20.8 & 47.02 & 0.442 & -0.354 \\
\hline ATP19.UE530.432 & & 27.05 & 47.02 & 0.575 & -0.240 \\
\hline ATP17.UE535.432 & & 26.27 & 47.02 & 0.559 & -0.253 \\
\hline ATP18.UE549.1288 & & 26.06 & 47.02 & 0.554 & -0.256 \\
\hline ATP14.UE99.1001 & Mt Bd & 47.36 & 82.59 & 0.573 & -0.242 \\
\hline ATP19.UE530.803 & & 51.2 & 82.59 & 0.620 & -0.208 \\
\hline ATP19.UE530.432 & & 52.06 & 82.59 & 0.630 & -0.200 \\
\hline ATP19.UE530.730 & Mc SD & 34.4 & 55.24 & 0.623 & -0.206 \\
\hline AP16.UE519.112 & & 47.8 & 55.24 & 0.865 & -0.063 \\
\hline ATP19.UE530.928 & & 33.1 & 55.24 & 0.599 & -0.222 \\
\hline ATP16.UE519.89 (uf) & & 30 & 55.24 & 0.543 & -0.265 \\
\hline ATP19.UE530.730 & Mc Dd & 33.8 & 48.4 & 0.698 & -0.156 \\
\hline AP16.UE519.112 & & 38.7 & 48.4 & 0.800 & -0.097 \\
\hline ATP16.UE519.89 & & 23.5 & 48.4 & 0.486 & -0.314 \\
\hline ATP19.UE530.730 & Mc BFd & 63 & 92.76 & 0.679 & -0.168 \\
\hline ATP19.UE530.730 & Mc BatF & 56.37 & 83.91 & 0.672 & -0.173 \\
\hline ATP16.UE519.89 (uf) & & 56.7 & 83.91 & 0.676 & -0.170 \\
\hline ATP19.UE530.730 & Mc $3=$ DEM & 24.74 & 37.5 & 0.660 & -0.181 \\
\hline ATP19.UE530.730 & Mc $6=\mathrm{DIL}$ & 32.3 & 44.52 & 0.726 & -0.139 \\
\hline
\end{tabular}

has been created to distinguish the males from the females (Fig. 4 and Table 5).

In the Neolithic, four of the eight first phalanges were grouped in the upper right area (ATP16.536.323; ATP19.UE537.60; ATP18.UE549.1143; ATP19.UE549.957), thus these most likely belonged to bulls. There is another one that is much larger than the rest, which is believed to belong to Bos primigenius (ATP19.UE530.550). Furthermore, three of the eight first phalanges are grouped in the lower left area (ATP18.UE530.952; ATP18.UE549.1286; ATP19.UE548.1171), thus most likely belonging to cows.

In the Chalcolithic, three of the 13 first phalanges (ATP14.UE79.389; ATP10.UE23.229; ATP08 O46UE9.26) fall within the upper right area, and thus they are considered bulls. Eight of the 13 are grouped in the lower left area (ATP09.UE52.606; ATP12.UE64.1311; ATP12.UE64.1274; ATP09.UE52.565; ATP08046UE4.128; ATP08 M47 UE4 128; ATP07M45.UE4.131; ATP08N46.UE4.135) and, thus, are considered cows.

In the Bronze Age levels, six of the phalanges are grouped in the lower left area (CMI-D4-55-3; CMI-C4-53-1; CMI-A2-55-1; CMI-D4-581; CMI-C4-72-1; CMI-D4-70-1; ATP19.UE2003N.864); therefore, all phalanges are considered cows.

Considering the sex determination using metacarpals and first phalanges of the domestic livestock, the ratio of bulls versus cows in the Neolithic at El Portalón is (5:4; 55.56\%:44.44\%). In the Chalcolithic, it is $(3: 10 ; 23.08: 79.92 \%)$ and in the Bronze Age, it is $(0: 9 ; 0: 100 \%)$.

The results of the multiproportion CIs indicate that there is overlapping between the confidence interval for bulls from the Neolithic, Chalcolithic, and Bronze Age and that there is overlapping between the confidence interval for cows from the Neolithic, Chalcolithic, and Bronze Age. Therefore, the proportion of males/females is not significantly different (Table 6).

\subsection{Changes in size: LSI}

The 128 raw data of the postcranial elements: 32 from the Neolithic (Table 7), 45 from the Chalcolithic (Table 8), and 51 from the Bronze Age (Table 9) from the El Portalón site have been included in order to apply LSI to the Ilford population.

LSI results indicate the Neolithic samples from El Portalón (mean $=-0.19$ ) display slightly higher means than the samples from the Chalcolithic (mean $=-0.206$ ), which display a slightly higher mean than the sample from the Bronze Age (mean = -0.239) (Fig. 5).

The results of the bootstrapping analysis indicate that the confidence interval between the means of the LSI for the Neolithic and the Chalcolithic samples overlap, such that they are not significantly different (probability of the error $<5 \%$ ). Moreover, the confidence interval between the means for the Chalcolithic and Bronze Age level samples do not overlap; thus, there is significant difference between the Chalcolithic and the Bronze Age. These results suggest that there are no differences in the size of the cattle between the Neolithic and Chalcolithic levels, but there is a significant decrease in cattle size from the Chalcolithic to the Bronze Age (Table 10).

\section{Discussion}

Many studies have supported the reduction in cattle size over the course of the Neolithic in the European context (Boessneck et al., 1971; Boessneck and Von Den Driesch, 1978; Lasota-Moskalewska, 1980; Tresset, 2000; Schibler and Schlumbaum, 2007). The decrease in cattle size continued throughout the Neolithic, Bronze Age, and Pre-Roman Iron Age in the European context, which is detected on a global and regional scale (Altuna, 1980; Ijzereef, 1981; Purugganan and Fuller, 2010; Manning et al., 2015).

The analysis of the size evolution for the El Portalón site substantiates the aforementioned observation. The El Portalón site's very 
Table 8

Postcranial element measurements for Chalcolithic bovines from the El Portalón site (Atapuerca), the standard population from the Ilford site, and LSI.

\begin{tabular}{|c|c|c|c|c|c|c|}
\hline cultural levels & label & VdD (1976) and Davis (1992, 1996) & measurem & standard & ratio & LSI \\
\hline \multirow[t]{3}{*}{ Pre-beaker } & ATP08.UE21.nivel7.64 & astragalo GLl & 64.05 & 95.15 & 0.673 & -0.172 \\
\hline & ATP08.UE21.80 & & 64 & 95.15 & 0.673 & -0.172 \\
\hline & ATP08.UE23.NIVEL7.136 & & 62.5 & 95.15 & 0.657 & -0.183 \\
\hline Pre-beaker (funerary) & ATP13.UE79a.172 & & 61.63 & 95.15 & 0.648 & -0.189 \\
\hline \multirow[t]{3}{*}{ Beaker } & ATP08.UE21.nivel7.64 & astragalo GLm & 57.84 & 87.33 & 0.662 & -0.179 \\
\hline & ATP08.UE21.80 & & 58 & 87.33 & 0.664 & -0.178 \\
\hline & ATP08.UE23.NIVEL7.136 & & 56.31 & 87.33 & 0.645 & -0.191 \\
\hline Pre-beaker (funerary) & ATP13.UE79a.172 & & 54.88 & 87.33 & 0.628 & -0.202 \\
\hline \multirow[t]{3}{*}{ Pre- Beaker } & ATP08.UE21.nivel7.64 & astragalus $\mathrm{Bd}$ & 39.88 & 66.7 & 0.598 & -0.223 \\
\hline & ATP08.UE21.80 & & 40.2 & 66.7 & 0.603 & -0.220 \\
\hline & ATP08.UE23.NIVEL7.136 & & 41.35 & 66.7 & 0.620 & -0.208 \\
\hline funerary context & ATP13.UE79a.172 & & 38.07 & 66.7 & 0.571 & -0.244 \\
\hline \multirow[t]{2}{*}{ Beaker } & АTP08 O45 UE16 39 & Calcaneo GL & 139.14 & 194.67 & 0.715 & -0.146 \\
\hline & ATP08 M47UE4.124 (fsing) & & 142.35 & 194.67 & 0.731 & -0.136 \\
\hline \multirow{2}{*}{ Beaker } & ATP08 O45 UE16 39 & Calcaneo GB & 43.21 & 75.83 & 0.570 & -0.244 \\
\hline & ATP08 M47UE4.124 (fsing) & & 45.53 & 75.83 & 0.600 & -0.222 \\
\hline Pre-Beaker & ATP09 UE21.85 & Femur DC & 43.6 & 67.57 & 0.645 & -0.190 \\
\hline Pre-Beaker (habitat) & ATP10.UE52.26 & Hu BT & 66.7 & 115.26 & 0.579 & -0.238 \\
\hline \multirow[t]{2}{*}{ Pre-beaker (funerary) } & ATP12.UE63.1361 & & 62.8 & 115.26 & 0.545 & -0.264 \\
\hline & ATP13.UE79.203 & & 67.84 & 115.26 & 0.589 & -0.230 \\
\hline Pre-Beaker (habitat) & ATP10.UE52.26 & Hu HTC & 28.3 & 50.42 & 0.561 & -0.251 \\
\hline \multirow[t]{2}{*}{ Pre-Beaker (funerary) } & ATP12.UE63.1361 & & 29.6 & 50.42 & 0.587 & -0.231 \\
\hline & ATP13.UE79.203 & & 29.25 & 50.42 & 0.580 & -0.236 \\
\hline Pre-Beaker & ATP08 UE23 184* & radio $\mathrm{Bd}$ & 82.48 & 110.25 & 0.748 & -0.126 \\
\hline \multirow[t]{2}{*}{ Beaker } & CMI-B6-83-29 & Ti Bd & 46.67 & 91.6 & 0.509 & -0.293 \\
\hline & ATP07O45UE16.108 & & 57.2 & 91.6 & 0.624 & -0.204 \\
\hline pre-Beaker & ATP08UE21.80 & & 62.3 & 91.6 & 0.680 & -0.167 \\
\hline Beaker & ATP07O45UE16.108 & Ti Dd & 40.7 & 69.23 & 0.588 & -0.231 \\
\hline Pre-Beaker & ATP08UE21.80 & & 43.5 & 69.23 & 0.628 & -0.202 \\
\hline P-B (funerary) & ATP12.UE64.1293 + 1275 & Mt Bd & 49.7 & 82.59 & 0.602 & -0.221 \\
\hline Pre-Beaker & ATP08.UE21.nivel7.86 & Mc SD & 32.8 & 55.24 & 0.594 & -0.226 \\
\hline Beaker & ATP08.UE4.046.72 & & 31.7 & 55.24 & 0.574 & -0.241 \\
\hline Pre-Beaker & ATP08.UE21.nivel7.86 & Mc Dd & 32.12 & 48.4 & 0.664 & -0.178 \\
\hline Beaker & ATP08.UE4.046.72 & & 29.31 & 48.4 & 0.606 & -0.218 \\
\hline Pre-Beaker & ATP08.UE21.nivel7.86 & Mc BFd & 59.23 & 92.76 & 0.639 & -0.195 \\
\hline Beaker & ATP08.UE4.046.72 & & 54.15 & 92.76 & 0.584 & -0.234 \\
\hline Pre-Beaker & ATP08.UE21.nivel7.86 & Mc BatF & 51.56 & 83.91 & 0.614 & -0.212 \\
\hline Beaker & ATP08.UE4.046.72 & & 49.48 & 83.91 & 0.590 & -0.229 \\
\hline Pre-Beaker & ATP08.UE21.nivel7.86 & Mc 3 = DEM & 24.7 & 37.5 & 0.659 & -0.181 \\
\hline Beaker & ATP08.UE4.046.72 & & 22.76 & 37.5 & 0.607 & -0.217 \\
\hline Pre-Beaker & ATP08.UE21.nivel7.86 & Mc $6=$ DIL & 28.57 & 44.52 & 0.642 & -0.193 \\
\hline Beaker & ATP08.UE4.O46.72 & & 26.14 & 44.52 & 0.587 & -0.231 \\
\hline Chalcolithic & АTP2011 & atlas BFcr & 105.83 & 140.18 & 0.755 & -0.122 \\
\hline
\end{tabular}

complete and continuous stratigraphic sequence, ranging from the Neolithic to the Chalcolithic and the Early and Middle Bronze Age, together with the abundance of bovine bone remains (constituting the second-best represented taxon in each level), allow for the detailed observation of the size variations for the cattle livestock. The results provided by the LSI technique indicate a slight decrease in bovine size from the Neolithic to the Bronze Age, whereas there is a more accentuated decrease in cattle size from the Chalcolithic to the Bronze Age (Fig. 5). Compared to other Iberian sites, the decrease in size of cattle livestock from the Neolithic to the Bronze Age was also identified in the Basque Country (such as the Neolithic, Chalcolithic and Bronze Age levels from the Arenaza, Marizulo and Los Husos sites; the Chalcolithic from the Urtiaga and Gobaederra site; the Bronze Age from Peñas de Oro, among others, Altuna, 1980). In this region, nevertheless, the cattle size decrease is concentrated from the Neolithic to the Chalcolithic, while there is hardly any size variation between the Chalcolithic and the Bronze Age (Altuna, 1980).

Nardone (2000) reported "a remarkable reduction in body size standards of cattle, sheep and goats breeds from north to south of the Mediterranean area related to the number of dry months" for modern livestock. A plausible explanation for the change in bovine size from the Chalcolithic to the Bronze Age could be related to the global trend towards aridification from the middle Holocene onwards (Carrión, 2002; Fletcher et al., 2013; Fletcher and Sánchez-Goñi, 2008; Jiménez-Espejo et al., 2014; Jiménez-Moreno et al., 2015) or to the 4.2 ka BP climatological event (Hinz et al., 2019), which represents an aridification event (Magny et al., 2009; Ruan et al., 2016). This event was identified in the El Portalón site through the study of the speleothems in the cave (Martínez-Pillado et al., 2014). Changes in demography, society, and subsistence strategies in the Iberian Peninsula were observed as consequences of this event (Hinz et al., 2019). According to the stalagmite study from the Cueva Mayor by Martínez-Pillado et al. (2014), around the fourth millennia BP in the El Portalón site, the environmental conditions became drier than before. This dryness caused the reduction of woodlands and nitrophilous taxa and increased the xeric taxa. Additionally, the soot-rich laminae (evidence of man-made fires) found in the stalagmite analysis suggest an increase in the human occupation and agricultural activity during the Bronze Age (Martínez-Pillado et al., 2014). These environmental changes observed in the El Portalón site during the Bronze Age could have affected cattle size during this period.

The increase in the human occupation during the Bronze Age (Martínez-Pillado et al., 2014) in El Portalón is similar to the MIR4 Middle Bronze Age at the El Mirador site (a site located very close to El Portalón, in the Sierra de Atapuerca) where an increase in anthropogenic indicators is observed, according to Expósito et al. (2017). The transformation of the landscape observed from MIR5 (Chalcolithic burial context) to MIR4 (Middle Bronze Age) is related to the intensification of human activities and climatic variation related to arid 
Table 9

Postcranial element measurements for Bronze Age level bovines at the El Portalón site (Atapuerca), the standard population from the Ilford site, and LSI.

\begin{tabular}{|c|c|c|c|c|c|}
\hline & measurem & standard & ratio & LSI & bibliography metrical data \\
\hline scapula SLC & 49.85 & 91.13 & 0.547 & -0.262 & (Galindo-Pellicena, 2014) \\
\hline \multirow[t]{5}{*}{ astragalo GLl } & 58.85 & 95.15 & 0.618 & -0.209 & (Galindo-Pellicena, 2014) \\
\hline & 57.35 & 95.15 & 0.603 & -0.220 & (Galindo-Pellicena, 2014) \\
\hline & 60.34 & 95.15 & 0.634 & -0.198 & (Galindo-Pellicena, 2014) \\
\hline & 58.15 & 95.15 & 0.611 & -0.214 & (Galindo-Pellicena, 2014) \\
\hline & 57.5 & 95.15 & 0.604 & -0.219 & \\
\hline \multirow[t]{6}{*}{ astragalo GLm } & 53.65 & 87.33 & 0.614 & -0.212 & (Galindo-Pellicena, 2014) \\
\hline & 50.91 & 87.33 & 0.583 & -0.234 & (Galindo-Pellicena, 2014) \\
\hline & 55.44 & 87.33 & 0.635 & -0.197 & (Galindo-Pellicena, 2014) \\
\hline & 51.99 & 87.33 & 0.595 & -0.225 & (Galindo-Pellicena, 2014) \\
\hline & 54.22 & 87.33 & 0.621 & -0.207 & (Galindo-Pellicena, 2014) \\
\hline & 52.4 & 87.33 & 0.600 & -0.222 & \\
\hline \multirow[t]{3}{*}{ astragalus $\mathrm{Bd}$} & 37.1 & 66.7 & 0.556 & -0.255 & (Galindo-Pellicena, 2014) \\
\hline & 36.4 & 66.7 & 0.546 & -0.263 & (Galindo-Pellicena, 2014) \\
\hline & 36.3 & 66.7 & 0.544 & -0.264 & \\
\hline Calcaneo GL & 109.36 & 194.67 & 0.562 & -0.250 & (Galindo-Pellicena, 2014) \\
\hline Calcaneo GB & 35.77 & 75.83 & 0.472 & -0.326 & (Galindo-Pellicena, 2014) \\
\hline \multirow[t]{2}{*}{ Femur DC } & 40.17 & 67.57 & 0.594 & -0.226 & (Galindo-Pellicena, 2014) \\
\hline & 40.5 & 67.57 & 0.599 & -0.222 & (Galindo-Pellicena, 2014) \\
\hline \multirow[t]{3}{*}{ Hu BT } & 76.97 & 115.26 & 0.668 & -0.175 & (Galindo-Pellicena, 2014) \\
\hline & 56.93 & 115.26 & 0.494 & -0.306 & \\
\hline & 72.6 & 115.26 & 0.630 & -0.201 & \\
\hline \multirow[t]{3}{*}{ Hu HTC } & 31.9 & 50.42 & 0.633 & -0.199 & (Galindo-Pellicena, 2014) \\
\hline & 26.92 & 50.42 & 0.534 & -0.273 & (Galindo-Pellicena, 2014) \\
\hline & 31.22 & 50.42 & 0.619 & -0.208 & \\
\hline radio $\mathrm{Bd}$ & 77.93 & 110.25 & 0.707 & -0.151 & (Galindo-Pellicena, 2014) \\
\hline \multirow[t]{4}{*}{ Ti Bd } & 52.11 & 91.6 & 0.569 & -0.245 & (Galindo-Pellicena, 2014) \\
\hline & 61.59 & 91.6 & 0.672 & -0.172 & (Galindo-Pellicena, 2014) \\
\hline & 52.24 & 91.6 & 0.570 & -0.244 & (Galindo-Pellicena, 2014) \\
\hline & 50.83 & 91.6 & 0.555 & -0.256 & (Galindo-Pellicena, 2014) \\
\hline \multirow[t]{4}{*}{ Ti Dd } & 36.28 & 69.23 & 0.524 & -0.281 & (Galindo-Pellicena, 2014) \\
\hline & 44.9 & 69.23 & 0.649 & -0.188 & (Galindo-Pellicena, 2014) \\
\hline & 40.02 & 69.23 & 0.578 & -0.238 & (Galindo-Pellicena, 2014) \\
\hline & 35.42 & 69.23 & 0.512 & -0.291 & (Galindo-Pellicena, 2014) \\
\hline Mt SD & 22.5 & 47.02 & 0.479 & -0.320 & (Galindo-Pellicena, 2014) \\
\hline \multirow[t]{2}{*}{ Mt Bd } & 49.12 & 82.59 & 0.595 & -0.226 & (Galindo-Pellicena, 2014) \\
\hline & 50.97 & 82.59 & 0.617 & -0.210 & (Galindo-Pellicena, 2014) \\
\hline \multirow[t]{3}{*}{ Mc SD } & 30.13 & 55.24 & 0.545 & -0.263 & (Galindo-Pellicena, 2014) \\
\hline & 28.1 & 55.24 & 0.509 & -0.294 & \\
\hline & 30.8 & 55.24 & 0.558 & -0.254 & \\
\hline Mc Dd & 27.8 & 48.4 & 0.574 & -0.241 & \\
\hline \multirow[t]{2}{*}{ Mc BFd } & 51 & 92.76 & 0.550 & -0.260 & \\
\hline & 54.2 & 92.76 & 0.584 & -0.233 & \\
\hline \multirow[t]{2}{*}{ Mc BatF } & 42.12 & 83.91 & 0.502 & -0.299 & \\
\hline & 45.5 & 83.91 & 0.542 & -0.266 & \\
\hline \multirow[t]{2}{*}{ Mc $3=\mathrm{DEM}$} & 20.5 & 37.5 & 0.547 & -0.262 & \\
\hline & 20.84 & 37.5 & 0.556 & -0.255 & \\
\hline \multirow[t]{2}{*}{ Mc $6=$ DIL } & 25.75 & 44.52 & 0.578 & -0.238 & \\
\hline & 25.5 & 44.52 & 0.573 & -0.242 & \\
\hline atlas BFcr & 79.52 & 140.18 & 0.567 & -0.246 & (Galindo-Pellicena, 2014) \\
\hline
\end{tabular}

episodes (Rodríguez-Cruz et al., 2016).

According to the sex determination, differences in the sex ratio throughout the different periods represented in the El Portalón sequence are observed; nevertheless, these differences are not statistically significant (see Table 5, where confidence intervals for the sex proportions overlap). Therefore, sexual dimorphism likely does not explain the changes in the cattle size from the Neolithic to the Bronze Age at this site. Due to the scarce bone remains of bovines from the El Mirador site, the metrical analysis for distinguishing the sex could not be carried out (Martín Rodríguez, 2015). The sex has been determined for some Iberian sites, such as the Early Neolithic at Valencina de la Concepción (Herman, 1982) and Zambujal (Driesch and Boesssneck, 1976) and the Chalcolithic and Beaker layer at Cerro de Virgen I-II (Von den Driesch and Boessneck, 1976), where the male to female ratio varies between levels, but there are no big differences (Pérez-Ripoll, 1999), which is similar for the El Portalón site.

\section{Conclusion}

El Portalón is an exceptional site due to its complete and continuous stratigraphic sequence, ranging from the Mesolithic to the Iron Age, and thus the evolution of the cattle exploitation can be studied with interesting results in relation to the subsistence strategy adopted by the inhabitants of the Meseta Castellana.

The cattle livestock constitute the second-best represented taxa in the Neolithic, the Early and Late Chalcolithic, and the Early Bronze Age. In the Middle Bronze Age, cattle constitute the best represented taxa.

The significant difference in cattle size between the Chalcolithic and Bronze Age does not appear to be related to the different sex ratio observed in each cultural level, and the similar subsistence strategy in the Chalcolithic and Bronze Age suggest that the most likely cause of this decrease in size could be the climate. The most significant change in cattle size is observed during the Chalcolithic-Bronze Age transition, which could coincide with the 4.2 ka climatic event, where social, demographic, and subsistence strategic changes occurred, or could be due to the global aridification experienced by the Iberian Peninsula from 


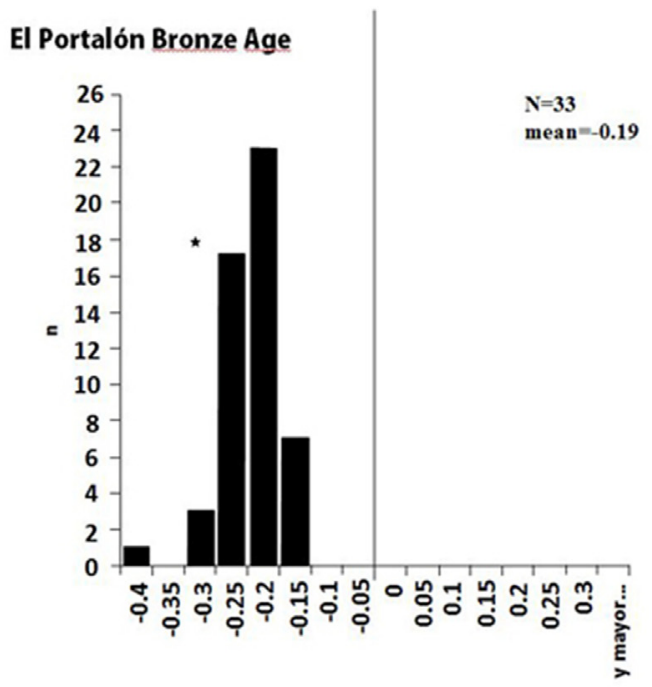

range

\section{El Portalón Chalcolithic}

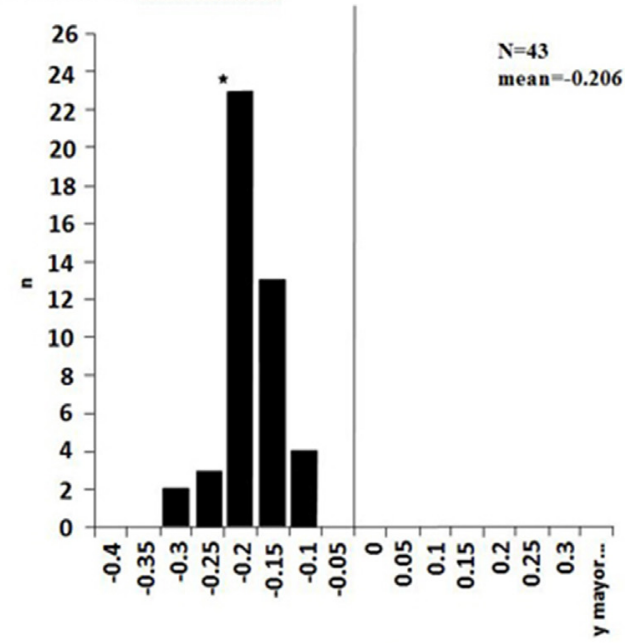

range

\section{El Portalón Neolithic}

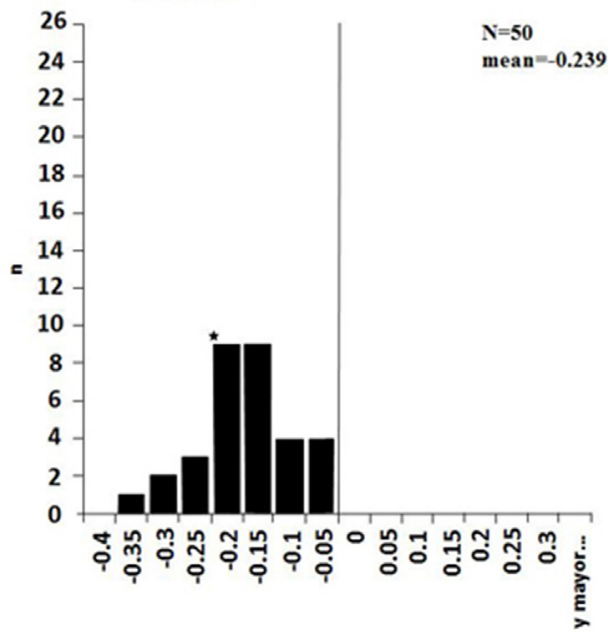

Fig. 5. Log ratio plots from Neolithic, Chalcolithic and Bronze Age levels of El Portalón sites. The mean is indicated by a star.
Table 10

Bootstrapping results of the LSI means for the postcranial elements of the Neolithic, Chalcolithic, and Bronze Age level cattle at the El Portalón site (Atapuerca, Burgos). LCI: lower confidence interval; UCI: upper confidence interval.

\begin{tabular}{llll}
\hline LSI & Neolithic & Chalcolithic & Bronze Age \\
\hline $\mathrm{N}$ & 33 & 43 & 50 \\
Min & -0.354 & -0.293 & -0.326 \\
Max & -0.063 & -0.122 & -0.151 \\
mean & -0.190 & -0.206 & -0.239 \\
LCI & -0.214 & -0.217 & -0.249 \\
UCI & -0.166 & -0.196 & -0.229 \\
\hline
\end{tabular}

the Neolithic onwards. Nevertheless, these results must be taken with caution since more data are necessary to corroborate this hypothesis.

\section{Declaration of competing interest}

The authors declare that they have no known competing financial interests or personal relationships that could have appeared to influence the work reported in this paper.

\section{Acknowledgments}

This study was financed by Ministerio de Economía y Competitividad, Spain Project PGC2018-093925-B-C33 (MCIU/AEI/ FEDER, UE). The field work at the Atapuerca sites is financed by the Junta de Castilla y León. We extend our sincerest gratitude to the team at the UCM-ISCIII Centre of Human Evolution and Behaviour, Fundación Atapuerca, and the Human Laboratory at the University of Burgos (UBU) for their technical support throughout the excavation. Special thanks are also due to the Portalón team for their support and effort throughout the course of the fieldwork. We are grateful to the Museum of Burgos for providing access to archaeological samples from the prior Portalón excavations, with special recognition to Marta Negro and to the Laboratorio de Evolución Humana team for their support. The thanks are extended to the two reviewers whose suggestions have improved the original manuscript. Currently, M.A.G.-P. has a technical support staff contract (PTA2018-015145-I) at the Fundación General de la Universidad de Alcala de Henares-Museo Arqueológico Regional (MAR) financed by Ministerio de Economía, Industria y Competitividad and the MAR

\section{References}

Albarella, U., Payne, S., 2005. Neolithic pigs from Durrington Walls, whiltshire, England: a biometrical database. J. Archaeol. Sci. 32, 589-599.

Altuna, J., 1980. Historia de la domesticación animal, en el País Vasco, desde sus orígenes hasta la romanización. Munibe 32, 9-163.

Altuna, J., Mariezkurrena, K., 2002. El problema de la domesticación de bovinos en el País Vasco y resto de la Región Cantábrica. Congresos de Estudios Vascos 15 $123-128$.

Arsuaga, J.L., Martínez, I., Gracia, A., Carretero, J.M., Lorenzo, C., García, N., Ortega, A.I., 1997. Sima de los Huesos (Sierra de Atapuerca, Spain). The site. J. Hum. Evol. 33, 109-127.

Audoin-Rouxeau, F., 1991. La taille du bouef domestique en Europe de l'Antiquité aux temps modernes. Fiches d'ostéologie animale pour l'archéologie, série B: mammifères $2,3-40$.

Barone, R., 1999. Anatomie Comparée des Mammifères Domestiques, Tome I and II. Vigot Frèges, Paris.

Bartosiewicz, L., 1998. Interim report on the Bronze age animal bones from arslatepe (malatya, anatolia). In: In: Buitenhuis, H., Bartosiewicz, L., Choyke, A.M. (Eds.), Archaeozoology of the Near East III, vol. 18. Groningen, ARC Publication, pp. 221-232 1998.

Boessneck, J., Von Den Driesch, A., 1978. Die Tierknochenfunde aus der Neolithischen Siedlung auf dem Fikirtepe bei Madiky am Marmarameer. München: Institut für Palaeoanatomie, Domestikationsforschungund Geschichte der Tiermedizin der Universität München.

Boessneck, J., Von Den Driesch, A., Meyer-Lemppenau, U., Wechsler Von Ohlen, E., 1971. Die Tierknochenfunde aud dem Oppidum von Manching. Die Ausgrabungen in Manching 6, Wiesbaden. 
Böyönki, S., y Bartosiewicz, L., 1987. Domestication and variation. Archaeozoologia 11, $161-170$

Carretero, J.M., Ortega, A.I., Juez, L., Pérez-González, A., Arsuaga, J.L., Pérez-Martínez, R., Ortega, M.C., 2008. A late pleistocene-early Holocene archaeological sequence of Portalón de Cueva mayor (sierra de Atapuerca, Burgos, Spain). Munibe 59, 67-80.

Carrión, J.S., 2002. Patterns and processes of Late Quaternary environmental change in a montane region of southwestern Europe. Quat. Sci. Rev. 21 (18-19), 2047-2066. https://doi.org/10.1016/S0277-3791(02)00010-0.

Castaños Ugarte, P.M., 2005. Estudio de la fauna de Cueva Mayor de Atapuerca. En: Mínguez, M. Estudios sobre Atapuerca (Burgos): III. Los materiales del Bronce Final del Portalón de Cueva Mayor. Cuadernos de Arqueología 20. Excma. Diputación de Burgos y Universidad de Deusto, pp. 247-257.

Chaix, L., 1994. L'Aurochs d'Etival et les Aurochs de Franche-comt e. Aurochs: le retour: Aurochs, vaches et autre bovins de la prehistoire a nos jours. Centre Jurassien du Patrimoine, Lons-le-Saunier, pp. 67e75.

Clark, G., Straus, L.G., Burton, S.S., Jackson-Clark, V., 1979. the north Burgos archaelogical survey: an inventory of cultural remains. In: Clark, G. (Ed.), The North Burgos Archaelogical Survey. Bronze and Iron Age archaeology on the Meseta del Norte (Province of Burgos, North-Central Spain) 19. Arizona. Arizona State University. Dept. of Antropology, pp. 18-156.

Clutton-Brock, J., 1999. A Natural History of Domesticated Mammals. Cambridge University Press, Cambridge.

Colledge, S., Conolly, J., Dobney, K., Manning, K., Shennan, S. (Eds.), 2013. The Origins and Spread of Domestic Animals in Southwest Asia and Europe. Leftcoast Press, Walnut Creek.

Cordier-Goni, P., 1938. L'Aurochs de Germanie d'apres le. Dr. Lutz Heck. La terre et la Vie (3), $77 \mathrm{e} 83$.

Davis, S.J.M., 1987. The Archaeology of Animals. Yale University Press, NewHaven. Davis, S., 1992. A Rapid Recording Method for Recording Information about Anima Bones from Archaeological Sites. English Heritage, London AML report 19/92.

Davis, S., 1996. Measurements of a group of adult female shetland sheep skeletons from a single flock: a baseline for zooarchaeologists. J. Archaeol. Sci. 23, 593e612.

Davis, S.J.M., Svensson, E.M., Albarella, U., Detry, C., Götherström, A., Pire, A.E., Ginja, C., 2012. Molecular and osteometric sexing of cattle metacarpals: a case study from 15th century AD Beja, Portugal. J. Archaeol. Sci. 39/5, 1445-1454.

Davis, S.J.M., Svensson, E.M., Albarella, U., Detry, C., Götherström, A., Pire, A.E., Ginja, C., 2013. Evidencia de mejoras de ovino y vacuno durante época andalusí y cristiana en Portugal a partir del análisis zooarqueológico y de adn antiguo. Debates de Arqueología Medieval 3, 241-287.

Davis, S., Albarella, U., Detry, C., Ginja, C., Götherström, A., Pires, A.E., Sendim, A., Svensson, E., 2018. An Osteometrical Method for Sexing Cattle Bones: the Metacarpals from 17th Century Carnide. Annalen des naturhistorischen Museums in Wien, Lisbon, Portugal Serie a. 120.

Expósito, I., Burjachs, F., Vergès, J.M., 2017. Human trace on the landscape during the Holocene at el mirador cave (sierra de Atapuerca, Spain): the palynological evidence. Holocene 27 (8), 1-13.

Falgueres, Ch, Bahai, J.J., Pérez-González, A., Mercier, N., Santonja, M., Dolo, J.M., 2006. The Lower Acheulian site of Ambrona, Soria (Spain): ages derived from a combined ESR/U-series model. J. Archaeol. Sci. 33, 149e157.

Fletcher, W.J., Sánchez-Goñi, M.F., 2008. Orbital- and sub-orbital-scale climate impacts on vegetation of the western Mediterranean basin over the last 48,000 yr. Quat. Res. 70 (3), 451-464. https://doi.org/10.1016/j.yqres.2008.07.002.

Fletcher, W.J., Debret, M., Sánchez-Goñi, M.F., 2013. Mid-Holocene emergence of a low frequency millennial oscillation in western Mediterranean climate: implications for past dynamics of the North Atlantic atmospheric westerlies. Holocene 23 (2), 153-166. https://doi.org/10.1177/0959683612460783.

Galindo-Pellicena, M.A., 2014. Estudio de la macrofauna de los niveles holocenos del yacimiento de El Portalón (sierra de Atapuerca, Burgos). Ph.D Thesis, Department of Paleontology, Complutense University of Madrid, Madrid.

Galindo-Pellicena, M.A., Martín-Francés, L., Gracia, A., De Gaspar, I., Arsuaga, J.L., Carretero, J.M., 2017. Evidences of the use of cattle as draught animals in Chalcolithic of El Portalón (Sierra de Atapuerca, Burgos). Quaternary International $438,1-10$.

Guintard, C., 1998. Ostéométrie des métapodes de bovines. Rev. Med. Vet. (Toulouse) 149/7, 751-770.

Guintard, C., 2005. Le cornage primigène (ou primigenius), caractéristiques, variabilité et intérêt pour l'aurochs-reconstitué. Rev. Paléobiol. 10, 259-269.

Guintard, C., Borvon, A., 2009. Sexer les métapodes de bovins: proposition de méthodologie appliqueé aus métacarpes. Exemple des sites archéologiques médiévaux d'Andone (Charente, X-XIe siècles) et de Montsoreau (Maine-et-Loire, XIe siècle). Bulletin de la Société des sciences naturales de l'Ouest de la France, Nouvelle série 31/3, 123-137.

Hain, F.H., 1982. Kupferzeitliche Tierknochenfunde aus Valencina de la Concepción, Sevilla. Studien uber frühe Tierknochenfunde von der Iberischen Halbinsel 8. Institut für Palaeoanatomie, Domestikationsforschung und Geschichte der Tiermedizin/ Deutsches Arch€aologisches Institut, München.

Helmer, D., Gourichon, L., Monchot, H., Peters, J., Saña-Segui, M., 2005. Identifying early domestic cattle from prepottery Neolithic sites on the middle Euphrates using sexual dimorphism. In: Vigne, J.D., Peters, J., Helmer, D. (Eds.), The First Steps of Animal Domestication. Oxbow Books, Oxford, pp. 86-95.

Herman, F., 1982. Kupferzeitliche Tierknochenfunde aus Valencina de la Concepción/ Sevilla. Studien über frühe Tierknochenfunde von der Iberischen Halbinsel, vol. 8 Institut für Palaeoanatomie, Domestikationsforschung und Geschichte der Tiermedizin/Deutsches Archäologisches Institut, München.

Higham, C.F.W., 1969. The metrical attributes of two samples of modern bovine bones. J. Zool. 157, 63-74.
Hinz, M., Schirrmacher, J., Kneisel, J., Rinne, C., Weinelt, M., 2019. The Chalcolithic-Bronze Age transition in southern Iberia under the influence of the 4.2 ka BP event? A correlation of climatological and demographic proxies JNA 21, 1-26. https://doi.org/10.12766/jna.2019.1. 2019.

Ijzereef, G.F., 1981. Bronze Age Animal Bones from Bovenkarspel. The Excavation at Het Valkje. Nederlanse Oudheden 10. ROB Project Noord-Holland 1. Amersfoort.

Jiménez-Espejo, F.J., García-Alix, A., Jiménez-Moreno, G., Rodrigo-Gámiz, M., Anderson, R.S., Rodríguez-Tovar, F.J., Martínez-Ruiz, F., Giralt, S., Delgado Huertas, A., PardoIgúzquiza, E., 2014. Saharan aeolian input and effective humidity variations over western Europe during the Holocene from a high altitude record. Chem. Geol. 374-375, 1-12. https://doi.org/10.1016/j.chemgeo.2014.03.001. 2014.

Jiménez-Moreno, G., Rodríguez-Ramírez, A., Pérez-Asensio, J.N., Carrión, J.S., LópezSáez, J.A., Villarías-Robles, J.J.R., Celestino-Pérez, S., Cerrillo-Cuenca, E., León, Á., Contreras, C., 2015. Impact of late-Holocene aridification trend, climate variability and geodynamic control on the environment from a coastal area in SW Spain. Holocene 25 (4), 607-617. https://doi.org/10.1177/0959683614565955.

Kurtén, B., 1968. In: Pleistocene Mammals of Europe. Aldine, Chicago.

Lasota-Moskalewska, A., 1980. Morphometric changes of domestic cattle skeleton from the Neolithic age to the beginning of the Iron Age. Wiadomści Archeologiczne 45, $119-167$.

Leithner, O. Von, 1927. Der Ur. Berichte der Internationalen Gesellschaft zur Erhaltung desWisents, Band II. Heft 1 2, 1e139.

Magny, M., Vanniere, B., Zanchetta, G., Fouache, E., Touchais, G., Petrika, L., Coussot, C., Walter-Simonnet, A.V., Arnaud, F., 2009. Possible complexity of the climatic event around $4300-3800 \mathrm{cal}$ BP in the central and western Mediterranean. Holocene 19 (6), 823-833. https://doi.org/10.1177/0959683609337360.

Manning, Katie, Timpson, Adrian, Shennan, Stephen, Crema, Enrico, 2015. Size Reduction in Early European Domestic Cattle Relates to Intensification of Neolithic Herding Strategies. Plos One 10 (e0141873), 1-19. https://doi.org/10.1371/journal. pone. 0141873 .

Martín Rodríguez, P., 2015. Caracterización zooarqueológica de las cuevas redil en la Prehistoria de la Meseta Norte: el caso de El Mirador (Sierra de Atapuerca, Burgos). Departamento de Historia, Historia del Arte y Autoecología Humana del Cuaternario. Universitat Rovira y Virgili, Tarragona.

Martínez-Pillado, V., Aranburu, A., Arsuaga, J.L., Ruiz-Zapata, B., Gil-García, M.J., Stoll, H., Yusta, I., Iriarte, E., Carretero, J.M., Lawrence Edwards, R., Cheng, H., 2014. Upper Pleistocene and Holocene palaeoenvironmental records in Cueva mayor karst (Atapuerca, Spain) from different proxies: speleothem crystal fabrics, palynology and archaeology. Int. J. Speleol. 43 (1), 1-14.

Matolcsi, J., 1970. Historische Erforschung der Körpergrösse des Rindes auf Grund von ungarischem knochenmaterial. Z. für Tierzuechtung Zuechtungsbiol. 63, 155-194.

Meadow, R., 1999. The use of size index scaling techniques for research on archaeozoological collections from the Middle East. In: Becker, C., Manhart, H., Peters, J., Schibler, J. (Eds.), Historiaanimalium ex ossibus. Festschrift Fur Angela von den Driesch. VerlagmarieLeidorf GmbH, pp. 285-300 Rahden/Westf.

Nardone, A., 2000. Weather conditions and genetics of breeding systems in the Mediterranean area. In: Enne, G., Greppi, G.F., Licita, G. (Eds.), Proc. Of the XXXX International Symposium of Società Italiana Per Il Progresso Della Zootecnia, pp. 67-92 Ragusa, Italy, 25th May, 2000.

Ortega, A.I., 2009. La evolución geomorfológica del Karst de la sierra de Atapuerca (Burgos) y su relación con los yacimientos pleistocenos que contiene. Tesis Doctoral inédita. Universidad de Burgos.

Ortega, A.I., Juez, L., Carretero, J.M., Arsuaga, J.L., Pérez-González, A., Ortega, M.C., Pérez, A., Rodríguez, A.D., García, R., Gómez, A., Rodríguez, L., Santos, E., Pérez, R. y Martínez, I., 2008. A new holocene archeological sequence from Portalón of Cueva Mayor (Sierra de Atapuerca, Burgos, Spain) BAR Internacional Series 1857, UISPP Proceeding of the XV World Congress 18 (Early Neolithic in the Iberian Peninsula, 3-10).

Pales, L., Garcia, M.A., 1981. Atlas ostéologiques pour servir à l'identification des mammifères du Quaternaire. CNRS, Paris.

Payne, S., Bull, G., 1988. Components of variation in measurements of pig bones and teeth, and the use of measurements to distinguish wild from domestic pig remains. Archaeozoologia 2, 27-66.

Pérez-Ripoll, M., 1999. La explotación ganadera durante el III milenio a.C. en la Península Ibérica. II congrés del Neolític a la Península Ibèrica. Sagvntvm-Plav, Extra- 2, 95-103.

Pérez-Romero, A., Carretero, J.M., Alday, A., Galindo-Pellicena, M.A., Adán, G., Juez, L., Arsuaga, J.L., 2015. La gestión del utillaje óseo de la Edad del Bronce en el yacimiento de El Portalón de Cueva Mayor, sierra de Atapuerca, Burgos. Complutum 26, $113-131$.

Pérez-Romero, A., Iriarte, E., Galindo-Pellicena, M.A., García-González, R., Rodríguez, L., Castilla, M., Francés, M., Santos, E., Valdiosera, C., Arsuaga, J.L., Alday, A., Carretero, J.M., 2017. An unusual Pre-bell beaker copper age cave burial context from El Portalón de Cueva Mayor site (Sierra de Atapuerca, Burgos). Quat. Int. 433, $142-155$.

Peters, J., Helmer, D., von den Driesch, A., Saña Segui, M., 1999. Early animal husbandry in the northern levant. Paleorient 25 (2), 27-48.

Poplin, F., 1983. Paleontologie des bovinae at origine des bovins domestiques. Ethnozootechnie 32, 4e15.

Purugganan, M.D., Fuller, D.Q., 2010. Archaeological data reveal slow rates of evolution during plant domestication. Evolution 65 (1), 171-183. https://doi.org/10.1111/j. 1558-5646.2010.01093.

Rodríguez-Cruz, A., Allúe, E., Buxo, R., 2016. Agriculture and livestock economy among prehistoric herders based on plant macroremains from El Mirador (Atapuerca, Burgos). Quat. Int. 414, 272-284.

Rowley-Conwy, P., 1995. Wild or domestic? On the evidence for the earliest domestic 
cattle and pigs in South Scandinavia and Iberia. Int. J. Osteoarchaeol. 5, 115-126.

Ruan, J., Kherbouche, F., Genty, D., Blamart, D., Cheng, H., Dewilde, F., Hachi, S. Edwards, R.L., Régnier, E., Michelot, J.L., 2016. Evidence of a prolonged drought ca. $4200 \mathrm{yr}$ BP correlated with prehistoric settlement abandonment from the Gueldaman GLD1 Cave, Northern Algeria. Clim. Past 12 (1), 1-14. https://doi.org/10.5194/cp12-1-2016. 2016.

Saña, M., 2013. Domestication of animals in the Iberian peninsula. In: Colledge, S., Conolly, J., Dobney, K., Manning, K., Shennan, S. (Eds.), The Origins and Spread of Domestic Animals in Southwest Asia and Europe, pp. 195-220 (Chapter 10).

Santonja, M., Pérez-González, A., Panera, J., Rubio-Jara, S., Sesé, C., Soto, E., SánchezRomero, L., 2014. Ambrona and Torralba archaeological and palaeontological sites, soria province. In: Sala, R. (Ed.), Pleistocene and Holocene Hunter-Gatherers in Iberia and the Gibraltar Strait: the Current Archaeological Record. Universidad de Burgos, Burgos, pp. 517-527.

Schibler, J., Schlumbaum, A., 2007. Geschichte und wirtschaftliche Bedeutung des Hausrindes (Bos taurus L.) in der Schweiz von der Jungsteinzeit bis ins fruhe Mittrlalter. Schweiz Arch Tierh 149, 23-29. https://doi.org/10.1024/0036-7281. 149.1.23.PMID:17243447.

Schmid, E., 1972. Atlas of Animal Bones: for Prehistorians, Archaeologists and Quaternary Geologists. Elsevier Science Ltd., Amsterdam.

Simpson, G.G., Roe, A., Lewontin, R.C., 1960. Quantitative Zoology. Harcourt Brace, New York.

Svensson, E., Götherström, A., 2008. Temporal fluctuations of Y-chromosomal variation in Bos taurus. Biol. Lett. 4, 752-754.

Tekkouk, F., Guintard, C., 2007. Approche ostéométrique de la variabilité des métacarpes de bovins et recherche de modèles applicables pour l'archéozoologie: cas de races rustiques françaises, algérienne et espagnoles. RMV (Rev. Med. Vet.) (Toulouse) 158, 388-396.

Telldahl, Y., Svensson, E.M., Götherström, A., Stora, J., 2012. Osteometric and molecular sexing of cattle metapodia. J. Archaeol. Sci. 39, 121-127.

Trentacoste, A., Nieto-Espinet, A., Valenzuela Lamas, S., 2018. Pre-Roman improvements to agricultural production: evidence from livestock husbandry in late prehistoric Italy. PloS One 13 (12), e0208109. https://doi.org/10.1371/journal.pone.0208109.

Tresset, A., 2000. Early husbandry in Atlantic areas. Animal introductions, diffusion of techniques and native acculturation at the north-western margin of Europe. In: Henderson, J. (Ed.), The Prehistory and Early History of Atlantic Europe. British Archaeological Reports. International Series, pp. 17-32.

Uerpmann, H.-P., 1978. Metrical analysis of faunal remains from the Middle East. In:
Meadow, R., Zeder, M.A. (Eds.), Approaches of Faunal Analysis in the Middle East. Peabordy museum, Cambridge, MA, pp. 41-45.

Valdiosera, C., Günther, T., Vera-Rodríguez, J.C., Ureña, I., Iriarte, E., Rodríguez-Varela, R., Simões, L.G., Martínez-Sánchez, R.M., Svensson, E.M., Malmströmb, H., Rodríguez, L., Bermúdez de Castr, J.M., Carbonell, E., Alday, A., Hernández Veral, J.A., Götherströmf, A., Carretero, J.M., Arsuaga, J.M., Smith, C.I., Jakobssonb, M. 2018. Four millennia of Iberian biomolecular prehistory illustrate the impact of prehistoric migrations at the far end of Eurasia. Proc. Natl. Acad. Sci. Unit. States Am. 115 (13), 3428-3433.

Valenzuela-Oliver, A., Alcover, J.A., Cau, M.A., 2013. Tracing changes in animal husbandry in mallorca (balearic islands, western mediterranean) from theIron age to the roman period. In: Groot, M., Lentjes, D., Zeiler, J. (Eds.), Barely Surviving or More than Enough? Sidestone Press, Leiden, pp. 201-223.

von den Driesch, A., 1972. Osteoarchaologische untersuchungen auf der Iberischen Halbinsel. Studien uber fruhe tierknochenfunde von der Iberischen Halbinsel, vol. 3. Deutsches Archaologisches Institut, Abeteilung Madrid, Munchen, pp. 1-267.

von den Driesch, A., 1976. A Guide to the Measurement of Animal Bones from Archaeological Sites, vol. 1 Peabody Museum Bulletin, Harvard M.A.

Von den Driesch, A., Boessneck, J., 1976. Die fauna vom Castro du Zambujal. In: Studien uber fruhe Tierknochenfunde von der Iberische Halbinsel, vol. 5. Institut fur Palaeoanatomie, Domestikationsforschung und Geschichte der Tiermedizin/ Deutsches Archaologisches Institut, Munchen, pp. 4-129.

Van Vuure, C., 2005. Retracing the Aurochs. History, Morphology and Ecology of an Extinct Wild Ox. Sofi a -Moscow. Pensoft Publishers.

Wright, L., 2013. The History of the European Aurochs from the Middle Pleistocene to its Extinction: an Archaeological Investigation of its Evolution, Morphological Variability and Response to Human Exploitation (PhD Thesis). University of Sheffield.

Wright, L., Viner-Daniels, S., 2015. Geographical variation in the size and shape of the European aurochs (Bos primigenius). J. Archaeol. Sci. 54, 8-22.

\section{Further reading}

Meadow, R.H., 1989. Osteological evidence for the process of animal domestication. In: Clutton-Brock, J. (Ed.), The Walking Larder: Patterns of Domestication, Pastoralism, and Predation. Unwin Hyman, London, pp. 80-90. 